U. S. DEPARTMENT OF THE INTERIOR

U. S. GEOLOGICAL SURVEY

\title{
GEOLOGIC OVERVIEW OF CLARK COUNTY, KANSAS
}

By Morris W. Green and George M. Fairer

U.S. Geological Survey, MS 913

Box 25046, Denver Federal Center, Denver, Colorado 80225

\section{Open-File Report 95-256}

This report is preliminary and has not been reviewed for conformity with U.S. Geological survey editorial standards or with the North American stratigraphic Code. Any use of trade, product, or firm names is for descriptive purposes only and does not imply endorsement by the U.S. Government. 


\section{CONTENTS}



1. Index map showing the location of U.S. Geological Survey 1:24,000-scale preliminary geologic maps and 7.5 minute topographic quadrangle maps in Clark County, Kansas 4

2. Schematic diagram showing the Great Plains and adjacent geologic provinces in relationship to clark County in south-central Kansas 6

3. Schematic diagram showing major basement structural features in westen Kansas 9

TABLES

1. Formation or unit name, age, summary description, and range in thickness (ft) of stratigraphic units which outcrop in clark County, Kansas 11

2. Geologic time scale and geologic units present in clark County, Kansas 


\section{ABSTRACT}

Clark County, in south-central Kansas adjacent to the oklahomaKansas boundary, is near the eastern edge of the Great Plains geologic province within the High Plains subprovince in a region characterized by long periods of tectonic stability. Sedimentary rocks composed of sediments deposited in marine and non-marine settings during the Paleozoic, Mesozoic and Cenozoic eras dominate the region and have been preserved from erosion by a wide-spread caprock formed by the Ogallala Formation of Tertiary age. In upland areas and along major drainage ways where the Ogallala caprock has been breached by erosion, older rocks are exposed in badlands throughout the High Plains subprovince from Nebraska to the panhandle of Texas.

The southern part of Clark County lies along the Cimarron River and its tributaries where extensive badlands have developed exposing Permian age marine red beds of fine- to very fine grained siltstone and sandstone separated by thin dolomite beds. Overlying the red beds and underlying the caprock are marine olive gray shales of Cretaceous age. Where the caprock is present in the northern part of Clark County, extensive deposits of Cenozoic eolian silt (loess), dune sand, and secondary calcium carbonate (caliche) overlie the caprock and form an area of fertile farm land. Extensive deposits of stream alluvium are present along the Cimmaron River and its major tributaries. Small landslide deposits also occur locally.

The dissolution of Permian age evaporite deposits in the subsurface by groundwater and subsequent collapse of overlying strata has produced numerous depressions that locally dot the landscape in the southern part of Clark and adjacent counties, particularly in areas along the Cimarron River. In 1992 a small collapse feature formed near the town of Ashland in the southern Clark County indicating that the sudden formation of collapse features poses a potential geologic hazard in the county and surrounding region.

\section{INTRODUCTION}

This report summarizes the geologic framework of Clark County, Kansas. It is a product of a U.S. Geological Survey (USGS) geologic mapping project conducted in cooperation with the Kansas Geological Survey (KGS) between 1991 and 1995. The primary objective of the project was met with completion of a series of six 1:24,000-scale geologic maps (maps $A-F$ on fig. 1) that cover the entire county.

Geologic information presented on geologic maps (fig. 1) and in this report is intended to aid the state and local government and the private sector in land use planning and management relating to issues such as geologic hazard mitigation (flooding along the Cimarron River, blowing sand and dust, and the formation of collapse features), soil stabilization, water quantity and quality, road and building construction. A secondary objective of the report and maps is to provide area residents with a better understanding of the geologic environment in which they live. The maps will also contribute to the compilation of a new geologic map of Kansas by the KGS. 


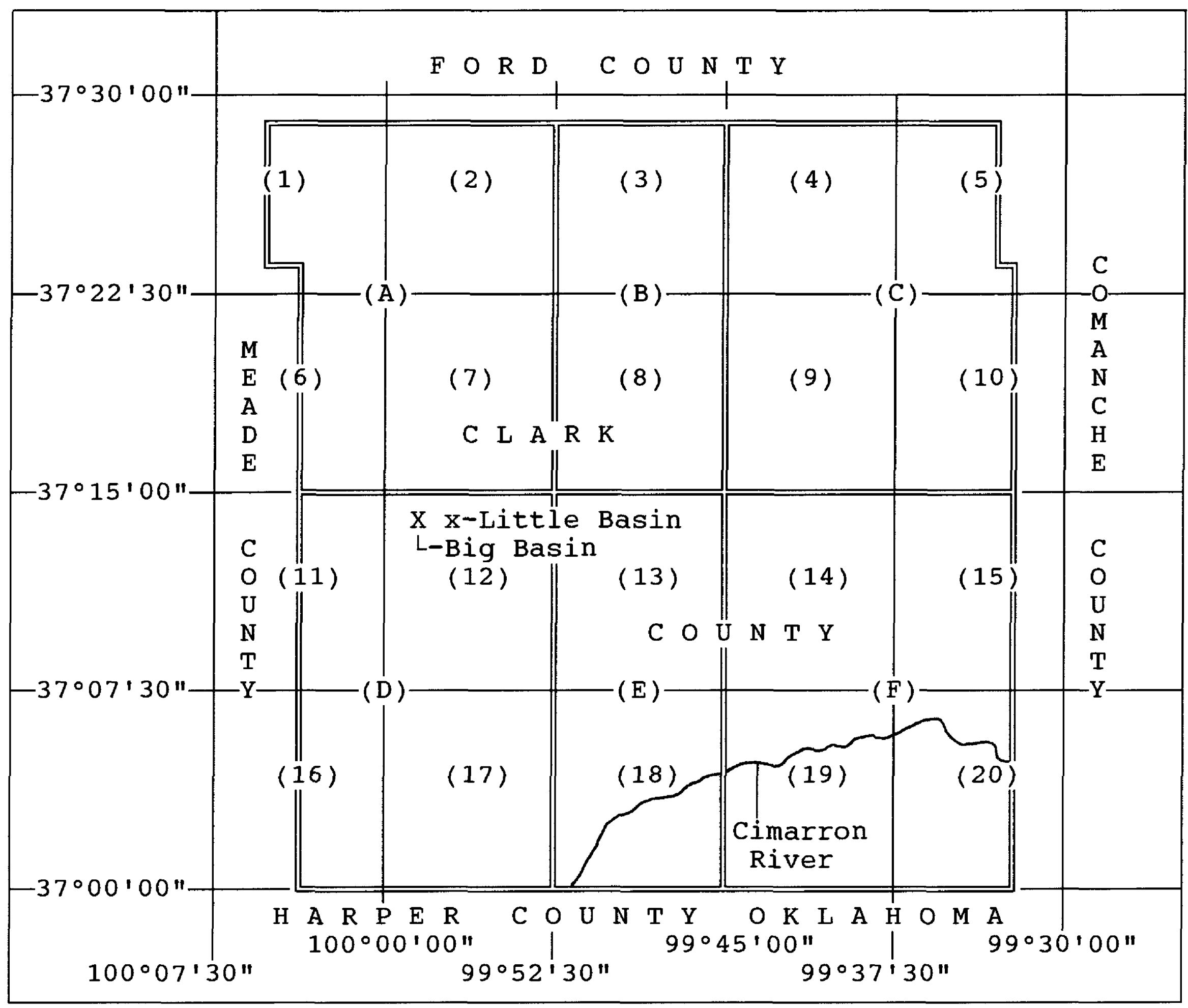

Figure 1. Index map showing the location of published 1:24,000-scale, preliminary geologic maps $(\mathbf{A}-\mathbf{F})$ and 7.5 minute topographic quadrangle maps (1-20) in Clark County, Kansas. The maps include:

(A) Bloom SW quadrangle and parts of the Bloom, Minneola, and Fowler SE quadrangles (Fairer and Green, 1992); (B) Bloom SE quadrangle and part of the Simmons Creek quadrangle (Green and Fairer, 1992); (C) Mount Jesus quadrangle and parts of the Mount Jesus NW, Lexington, and Turkey Creek quadrangles (Green and Fairer, 1994a); Ashland NW quadrangle and parts of the Englewood, Profitt Lake, and Mount Helen quadrangles (Fairer and Green, 1994a); (E) Ashland quadrangle and part of the Ashland SE quadrangle (Fairer and Green, 1994b); (F) Sitka quadrangle and parts of the Sitka SW, Sugarloaf, and Trout Creek quadrangles (Green and Fairer, 1994b)

(1) Minneola, (2) Bloom, (3) Simmons Creek, (4) Mount Jesus NW, (5) Turkey Creek, (6) Fowler SE, (7) Bloom SW, (8) Bloom SE, (9) Mount Jesus, (10) Lexington, (11) Profitt Lake, (12) Ashland NW, (13) Ashland, (14) Sitka, (15) Sugarloaf, (16) Mount Helen, (17) Englewood, (18) Ashland SE, (19) Sitka SW, (20) Trout Creek 
Acknowledgments.--The authors acknowledge the financial support given during the project by the KGS. Christopher G. Maples and Lawrence L. Brady of the KGS coordinated and sponsored the project. The authors also benefited greatly from their interaction with other KGS members including Jim McCauley and Rex Buchannan who led an informative field excursion through the Clark and adjacent counties in 1992. Their encouragement, guidance, and role as providers of critical information on past work in the project area was most helpful.

\section{PREVIOUS WORK}

Ada Swineford, geologist and former member of the KGS, conducted geologic research in clark county during the 1950's. Swineford described the petrology, depositional setting, and correlation of Permian red beds in the county (Swineford, 1955). Her work is a valuable contribution to the stratigraphy and the identification of probable source areas of the stratigraphic units. Most other references to the geology of Clark County have been in the context of regional studies such as those of D.F. Merriam (1963), M.R. Mudge (1967), and D.E. Zeller (1968).

\section{PHYSIOGRAPHIC SETTING}

Clark County, in the south-central Kansas, adjacent to the Oklahoma-Kansas boundary, is in the High Plains subprovince of the Great Plains geologic province (Shimer, 1972). The Great Plains province is elongate north-south from Canada to Mexico and forms a 300 to 500 mile-wide belt approximately between the 100th Meridian and the eastern flank of the Rocky Mountains (fig. 2).

The Great Plains geologic province is characterized by tectonic stability and the presence of thick layers of horizontally bedded shale, siltstone, sandstone, conglomerate, and evaporite, much of which is the result of long periods of sedimentation in marine, nearshore marine, and terrestrial depositional settings during the Cenozoic, Mesozoic, and Paleozoic Eras. There is a notable lack of faulting and folding locally; however, regionally, broad gentle upwarps and downwarps form broad shallow basins and highland areas. Most of the topography in the province is erosional and related to downcutting by streams. On the western edge of the province, at its boundary with the adjacent Rocky Mountain and Basin and Range geologic provinces, stratigraphic units are sharply upturned along the mountain front. Elsewhere, over much of the Great Plains province, stratigraphic units are preserved from erosion by the presence of a widespread caprock formed by the ogallala Formation of Tertiary age. The Ogallala is a regional aquifer that underlies the High Plains subprovince from Nebraska south to the Texas panhandle. In turn, Cenozoic deposits of eolian sand, loess, and caliche (secondary calcium carbonate) mantle the caprock and adjacent areas and form the parent materials of the extensive fertile soils that cover much of the mid-continent area. Eolian sand and loess in the Mid-continent are probably derived in part from local sources such as the ogallala Formation and in part from distant sources such as the widespread Pleistocene glacial outwash deposits in the northern part of the province and in the Great Lakes region to the northeast. 


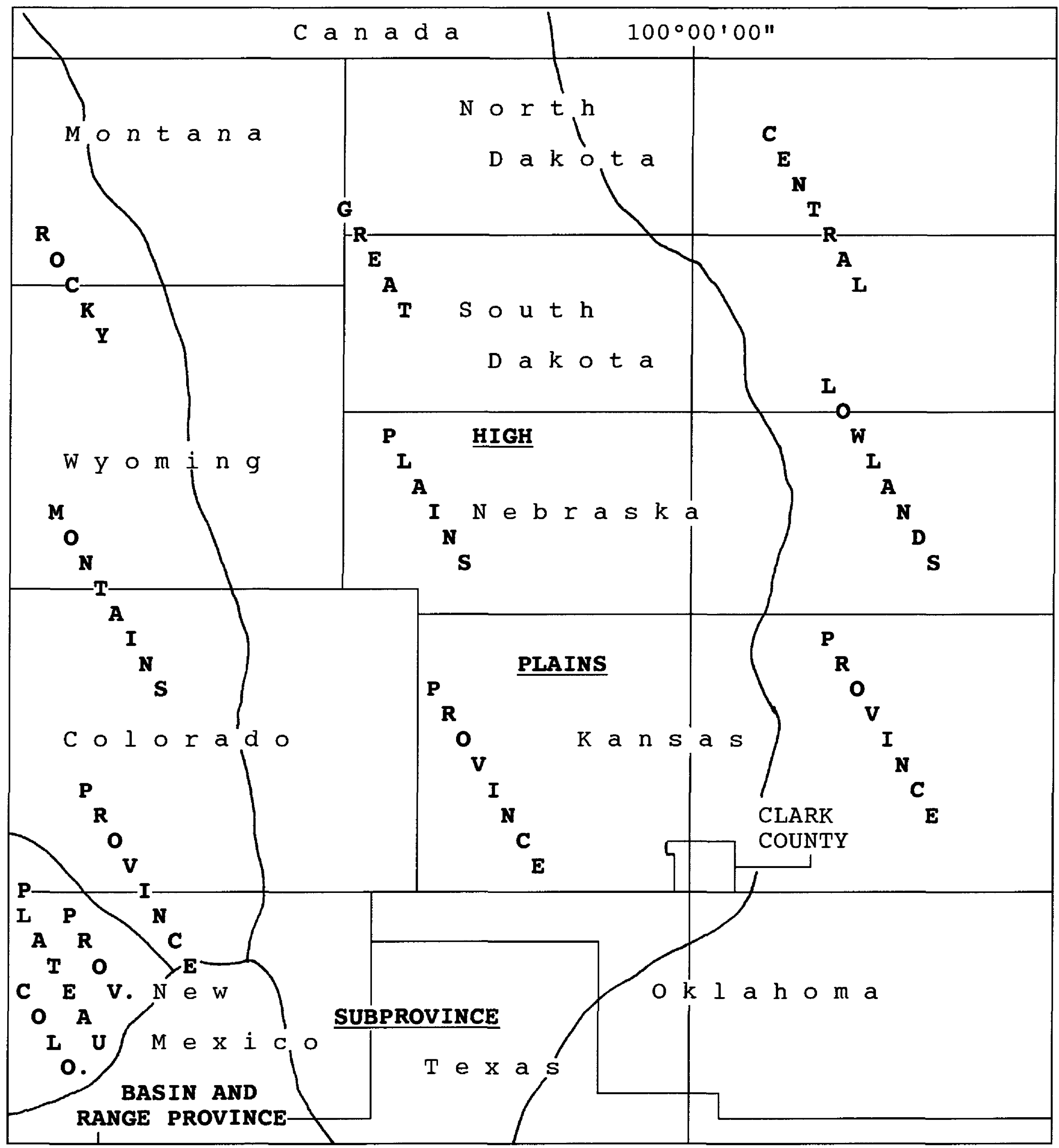

Figure 2. Schematic diagram showing the Great Plains and adjacent geologic provinces in relationship to Clark County in the southcentral part of the Kansas. (Modified from Shimer, 1972) 
Although the Great Plains province is dominated by rolling plains commonly devoid of unique geologic features, it does contain local areas of badlands topography created by erosion of upland areas and areas adjacent to major streams where the Ogallala caprock has been breached. Older formations, many of which are red beds of Permian and Pennsylvanian age, generally crop out in these badlands areas to form spectacular bedrock exposures.

The southern part of Clark County lies along the Cimarron River and its tributaries where an extensive badlands has developed exposing Permian age red beds of fine- to very fine grained siltstone and sandstone separated by thin dolomite beds. Badlands, known locally as the "Red Hills," form the county's most pronounced geomorphic feature. The badlands contains numerous hills and gullies cut into the red beds. Maximum topographic relief is several hundred feet. In the badlands area grassland vegetation is restricted to gentler hillsides and flood plains adjacent to tributary streams. Most of the badlands area is not suitable for farming because of rugged topography and widespread barren bedrock that lacks agricultural soil. The badlands area is thus better suited to ranching than to farming. A notable exception is the flood plain of the Cimarron River where crops are locally grown, particularly on the northern side of the river and in areas free of sand dunes. Dune fields on the flood plain are locally prominant geomorphic features characterized by hummocky topography. Within the badlands area the Permian sequence is unconformably overlain by dark-gray fossiliferous, micaceous shale beds of Cretaceous age.

The northern part of clark county is underlain by the ogallala caprock mantled by extensive deposits of loess, dune sand, and secondary calcium carbonate. Locally, these carbonate deposits are referred to as "caliche" or "calcrete". These deposits serve as a primary source of road metal throughout clark county and the adjacent region. Farming is dominant in the northern part of the county on thick loess deposits. Extensive pre-quaternary soil development has occurred on the Ogallala. Adjacent to the Cimarron River in the southern part of the county, vast dune fields composed of eolian sand are common and were formed by wind erosion, transport, and deposition of sand derived from the sandy alluvium of Cimarron River flood plain.

The dissolution of Permian age evaporite deposits in the subsurface by groundwater and subsequent collapse of overlying strata has produced numerous depressions that dot the landscape in the southern part of $\mathrm{Clark}$ and adjacent counties. Prominant collapse features in Clark County include "Big Basin" (sec. 25, T. 32 S., R. 25 W.) and an accompanying depression about one-half mile to the east (sec. 30, T. 32 S., R. 24 W.) known as "Little Basin". These features are located in the western part of the county several miles north of the Cimarron River (Fairer and Green, 1994a). Highway 160 between Ashland and Dodge City traverses Big Basin. Big Basin is approximately one mile in diameter and has a maximum relief of approximately $200 \mathrm{ft;}$ whereas, Little Basin is approximately onequarter mile wide and is about 75-100 ft deep. Neither of these features has an exterior drainage. 
Collapse features in the county such as these basins apparently vary widely in age of formation; some form rapidly while others form slowly. These basins show evidence of multiple stages of collapse and erosion indicating their formation has occurred over a long period of time. Little Basin shows evidence of some recent collapse activity by the presence of several small concentric, uneroded faults in the vicinity of St. Jacob's well, a water-filled collapse sink within the main depression.

In 1992, a small collapse feature formed abruptly approximately 10 miles east of Ashland in Clark County (Jim McCauley of the KGS, oral communication, 1992) indicating that the formation of collapse features poses a potential geologic hazard in the region.

Jim McCauley also noted that collapse features seem to be aligned parallel to the Cimarron River and commonly occur just north of the river and near its tributaries suggesting that dissolution of subsurface evaporite deposits may be linked to subsurface groundwater recharge along the river. The presence of numerous depressions in the Cimarron River floodplain (Green and Fairer, 1994b) suggests these features may be the sites of aquifer recharge. These depressions are commonly filled by ponds that lack exterior drainage. McCauley also suggests that subsidence may be advancing northward from the river along a subsurface solution front controlled by riverine recharge in the subsurface.

\section{STRUCTURAL GEOLOGY}

Local faulting and folding is rare in Clark and adjacent counties. One small concentric fault and a small linear fault have been mapped in the vicinity of Big and Little basins in the northwestern part of the county as shown on the geologic map of that area by Fairer and Green (1994a). A third small fault, trending northwest-southeast, has been mapped in the southeastern part of the county (Green and Fairer, 1994b). The latter fault is buried under flood plain sediment of the Cimarron River in the southeastern part of the county and is inferred by a linear trend in a single outcrop and the presence of a $2^{\circ}$ dip in adjacent bedrock outcrops. The faults at Big and Little basin apparently formed in association with the development of the collapse structures.

Tectonic stability dates back to Precambrian time, is regional in extent, and is attributed to the presence of a thick, rigid interior craton, an extension of the Canadian shield, underlying the entire mid-continent. Only a few broad, large-scale, upwarps and downwarps have influenced Paleozoic, Mesozoic, and Cenozoic sedimentation patterns in the region.

During the formation of Permian red beds the region in the vicinity of Clark County lay on the eastern flank of the Hugoton embayment, a shelf-like extension of the Anadarko basin located in central and northern Oklahoma (Maher and Collins, 1949), a failed northwest-southeast trending rift basin, located in central and northern oklahoma. The Hugoton embayment covers all of western Kansas and is bounded on the northeast and east by the central Kansas uplift, the Cambridge arch, and Pratt anticline as shown schematically on figure 3 (Stewart, 1975). The western side of the embayment is bounded by the Las Animas arch in eastern Colorado. 


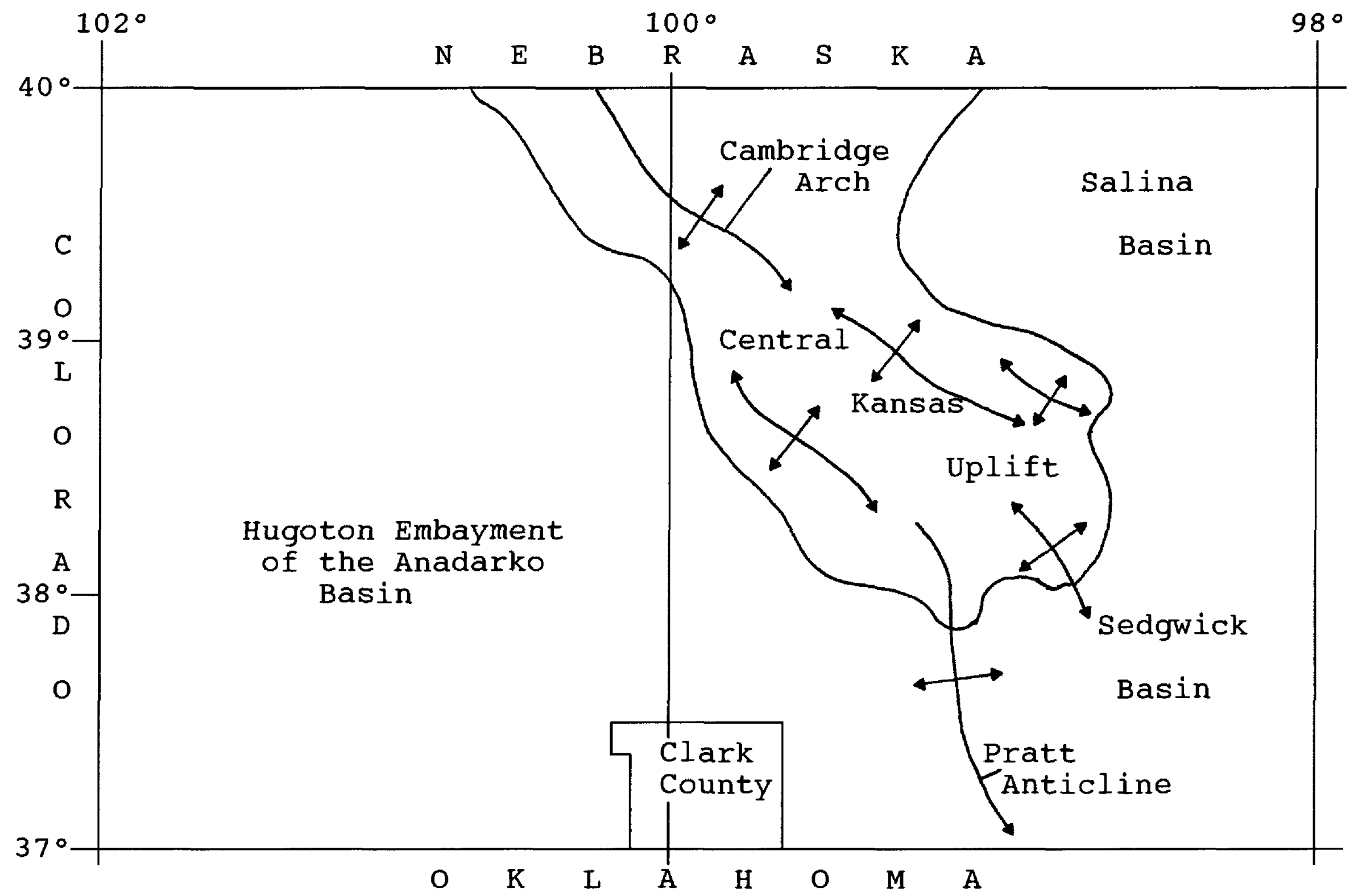

Figure 3. Schematic diagram showing major basement structural features in westen Kansas during the Paleozoic Era (Modified from Stewart, 1975) 
The embayment forms is a shelf-like northern extension off the main axis of the Anadarko. In Kansas, the maximum relative downwarp of the embayment floor is about 9,500 feet. The areal extent of the embayment and its large floor-to-crest throw make it the largest geologic structure in the state (Merriam, 1963, p. 181).

During the Mesozoic Era Clark County lay within the newly forming Rocky Mountain geosyncline in the Western Kansas basin, a broad northsouth trending subbasin bounded on the west-southwest by the Las Animas arch and on the east-northeast by remnants of the central Kansas uplift and its extensions, the Cambridge arch on the northwest and the Chautauqua arch on the southeast.

Cretaceous shale and sandstone in the Clark County region (Kiowa Formation in Clark County and the Cheyenne Sandstone in adjacent Comanche county) were formed from sediments deposited while an inland sea occupied the Rocky Mountain geosyncline, a large trough-like tectonic feature which spanned the mid-continent and western interior of North America from north to south during the Cretaceous period. These marine units are composed of sediment derived from uplifts on the western margin of the geosyncline, i.e., the Mesocordilleran geanticline, a large uplifted area which occupied the entire western margin of the continent during most of the Mesozoic Era. With uplift of the geosyncline and withdrawal of the Cretaceous sea during the Laramide orogeny ( 80 to $40 \mathrm{Ma}$ ) which formed the Rocky Mountains, the Clark county region became the site of wide-spread sedimentary deposition by wind and water on a broad riverine plain which lay east of the Rocky Mountains. Sediments deposited on the riverine plain comprise the Ogallala Formation.

\section{STRATIGRAPHY AND SEDIMENTARY DEPOSITIONAL ENVIRONMENTS}

Downcutting by the Cimarron River and its tributaries including Keiger, Bluff, Day, and Sandy Creeks has exposed up to about 500 ft of stratigraphic section along these drainages. Outcrops occur in badlands along these drainages and contain (in descending stratigraphic order) a) unconsolidated sediments of Holocene and Pleistocene age overlying the Tertiary ogallala caprock, b) rocks of Cretaceous, and c) rocks of Upper and Lower Permian age (Tables 1 and 2).

Triassic and Jurassic age rocks were eroded or were not deposited in Clark County, but are present west of the county in the southwestern part of the state.

older rocks of Lower Mesozoic, Lower Paleozoic, and Precambrian age in Clark County are deeply buried. Upper Mesozoic and Upper Paleozoic rocks consist of alternating marine and nonmarine limestone, shale, siltstone, and sandstone interbedded with thin beds of dolomite and thick deposits of gypsum/anhydrite and other evaporitic salts. Much of this sequence is composed of sediment deposited within cyclothems, i.e., sequences of sediment deposited by recurring or repetitive depositional conditions. Precambrian rocks, known only from deep drill holes in the state, are of granitic composition in Clark County (Merriam, 1963, p. 156). Lower Paleozoic rocks crop out in counties east of Clark County. 


\begin{tabular}{|c|c|c|c|}
\hline FORMATION/UNIT & AGE & SUMMARY DESCRIPTION & THICKNESS \\
\hline $\begin{array}{l}\text { Alluvium } \\
\text { Loess } \\
\text { Dune sand } \\
\text { Calcium } \\
\text { Carbonate } \\
\text { Landslide } \\
\text { deposits }\end{array}$ & $\begin{array}{l}\text { Quaternary } \\
\text { (Holocene } \\
\text { and } \\
\text { Pleistocene) }\end{array}$ & $\begin{array}{l}\text { Surficial deposits of } \\
\text { stream-deposited gravel, } \\
\text { sand, and silt; uncon- } \\
\text { solidated, wind-blown sand, } \\
\text { silt, and clay; "caliche" } \\
\text { or calcium carbonate } \\
\text { deposited in and on } \\
\text { surficial deposits and } \\
\text { bedrock units; and unsorted } \\
\text { and unstratified rock } \\
\text { debris }\end{array}$ & $0-120$ \\
\hline $\begin{array}{l}\text { Ogallala } \\
\text { Formation }\end{array}$ & $\begin{array}{l}\text { Tertiary } \\
\text { (Pliocene) }\end{array}$ & $\begin{array}{l}\text { Variegated conglomerate, } \\
\text { conglomeratic sandstone. } \\
\text { siltstone, and calcium } \\
\text { carbonate (caliche). }\end{array}$ & $0-80$ \\
\hline $\begin{array}{l}\text { Kiowa } \\
\text { Formation }\end{array}$ & $\begin{array}{l}\text { Lower } \\
\text { Cretaceous }\end{array}$ & $\begin{array}{l}\text { Dark gray, carbonaceous, } \\
\text { micaceous shale, silt- } \\
\text { stone, and fine- to very } \\
\text { fine grained sandstone; } \\
\text { locally fossiliferous. }\end{array}$ & $0-100$ \\
\hline $\begin{array}{l}\text { Big Basin } \\
\text { Formation }\end{array}$ & $\begin{array}{l}\text { Upper } \\
\text { Permian }\end{array}$ & $\begin{array}{l}\text { Reddish-brown siltstone, } \\
\text { silty sandstone, and very } \\
\text { fine grained sandstone. } \\
\text { Locally montmorillinitic } \\
\text { and dolomitic. }\end{array}$ & $0-100$ \\
\hline $\begin{array}{l}\text { Day Creek } \\
\text { Dolomite }\end{array}$ & $\begin{array}{l}\text { Upper } \\
\text { Permian }\end{array}$ & $\begin{array}{l}\text { Light tan dolomite. Locally } \\
\text { contains silt and forms a } \\
\text { prominent resistant } \\
\text { marker horizon within the } \\
\text { Permian sequence. }\end{array}$ & $0-2$ \\
\hline $\begin{array}{l}\text { Whitehorse } \\
\text { Formation }\end{array}$ & $\begin{array}{l}\text { Upper } \\
\text { Permian }\end{array}$ & $\begin{array}{l}\text { Reddish-orange siltstone, } \\
\text { sandy siltstone, and } \\
\text { very fine grained sand- } \\
\text { stone. Locally contains } \\
\text { spherical sandstone con- } \\
\text { cretions and is gyp- } \\
\text { siferous. }\end{array}$ & $150-250$ \\
\hline $\begin{array}{l}\text { Blaine } \\
\text { Formation }\end{array}$ & $\begin{array}{l}\text { Lower } \\
\text { Permian }\end{array}$ & $\begin{array}{l}\text { Light gray gypsum with } \\
\text { minor interbeds of } \\
\text { reddish-brown shale and } \\
\text { siltstone. }\end{array}$ & $0-50$ \\
\hline
\end{tabular}

Table 1. Formation or unit name, age, summary description, and range in thickness (ft) of stratigraphic units which crop out in clark County, Kansas 


\begin{tabular}{|c|c|c|c|}
\hline $\begin{array}{l}\text { ERA } \\
\text { SYSTEM OR PERIOD } \\
\text { SERIES OR EPOCH }\end{array}$ & $\begin{array}{l}\text { APPROX. } \\
\text { NUMBER OF } \\
\text { MILLION } \\
\text { YEARS AGO }\end{array}$ & $\begin{array}{l}\text { APPROX. } \\
\text { LENGTH, } \\
\text { MILLIONS } \\
\text { OF YEARS }\end{array}$ & $\begin{array}{l}\text { FORMATION OR STRATIGRAPHIC } \\
\text { UNITS PRESENT OR ABSENT } \\
\text { IN CLARK COUNTY }\end{array}$ \\
\hline $\begin{array}{l}\text { CENOZOIC } \\
\text { Quaternary } \\
\text { Holocene } \\
\text { Pleistocene }\end{array}$ & $0-1$ & 1 & $\begin{array}{l}\text { Alluvium, loess, dune sand, } \\
\text { calcium carbonate } \\
\text { ("caliche"), and land- } \\
\text { slide deposits }\end{array}$ \\
\hline $\begin{array}{l}\text { Tertiary } \\
\text { Pliocene }\end{array}$ & $1-13$ & 12 & Ogallala Formation \\
\hline Miocene & $13-25$ & 12 & \\
\hline Oligocene & $25-36$ & 11 & \\
\hline Eocene & $36-58$ & 22 & -Absent in Clark county \\
\hline Paleocene & $58-63$ & 5 & \\
\hline $\begin{array}{l}\text { MESOZOIC } \\
\text { Cretaceous }\end{array}$ & $63-135$ & 72 & Kiowa Formation \\
\hline$\frac{\text { Jurassic }}{\text { Triassic }}$ & $\frac{135-181}{181-230}$ & $\left.\frac{46}{49}\right]$ & -Absent in Clark County \\
\hline $\begin{array}{l}\text { PALEOzOIC } \\
\text { Permian } \\
\text { Pennsylvanian } \\
\text { Mississippian }\end{array}$ & $\begin{array}{l}230-280 \\
280-310 \\
310-345\end{array}$ & $\begin{array}{l}50 \\
\frac{30}{35}\end{array}$ & $\begin{array}{l}\text { Big Basin Formation } \\
\text { Day Creek Dolomite } \\
\text { Whitehorse Formation } \\
\text { Blaine Formation }\end{array}$ \\
\hline Devonian & $345-405$ & 60 & \\
\hline Silurian & $405-425$ & 20 & Present only in subsurface \\
\hline ordovician & $425-500$ & 75 & \\
\hline Cambrian & $500-600$ & $100]$ & \\
\hline PRECAMBRIAN & $600-2,500+$ & $1,900+$ & - Present only in subsurface \\
\hline
\end{tabular}

Table 2. Geologic time scale and geologic units present and absent in Clark County, Kansas. (Modified from D.F. Merriam, 1963, p. 175) 
Quaternary Period

Alluvium, loess, dune sand, secondary calcium carbonate ("caliche"), and land-slide deposits (Holocene and Pleistocene)

Unconsolidated deposits of Holocene and Pleistocene age (Table 2) blanket widespread areas of the county. In the northern part of the county where these deposits are underlain by the ogallala Formation caprock, they attain thicknesses up to $120 \mathrm{ft}$ and consist mainly of silt and sandy silt (loess), and sand with lesser amounts of gravel and secondary calcium carbonate (caliche). The main agents of erosion, transport and deposition have been water in streams, ponds, and lakes and the wind on eolian dune fields and loess sheets. These deposits also blanket upland areas below the caprock in the southern part of the county where deposits are generally much thinner and contain a high percentage of loess indicating that the primary modes of erosion, transport, and deposition of these sediments was wind.

Unconsolidated gravel deposits derived predominantly from stream erosion of the Ogallala Formation are generally restricted to upland areas where present-day streams traverse the landscape and the flood plain of the Cimarron River. Although sparse, these gravel deposits provide and important source of aggregate for road construction and the building industry within the county. Location of open-pits in gravel and caliche deposits are shown on topographic and geologic maps of the county with a crossed pick and shovel symbol.

Deposits of detrital sediment are frequently accompanied by deposits of secondary calcium carbonate precipitated within interstitial pore spaces of near-surface sediment and soil horizons. These deposits, are also known as "caliche" or "calcrete" where they are white and contain abundant secondary calcium carbonate. Deposits that contain minor to abundant secondary calcium carbonate are widespread in the county and vary in thickness, but may become several tens of feet thick locally. Calcium carbonate deposits, mined in several areas of the county, are used as metal for all-weather road construction throughout the region.

\section{Tertiary Period}

\section{Ogallala Formation (Pliocene)}

Rocks of the Tertiary period are contained in the ogallala Formation of Pliocene age and include deposits of conglomerate, sandstone, siltstone (loess), and calcium carbonate (caliche/calcrete) deposited in a variety of terrestrial depositional settings including stream-channel, flood-plain, pond, lacustrine, and eolian environments similar to those environments present today in south-central Kansas. Locally, the Ogallala contains an appreciable quantity of opaline silica with an oolitic texture. The silica has replaced calcium carbonate. The formation locally contains fossil remains of both vertebrate and invertebrate animals and forms a widespread resistant 60-120 ft thick caprock in the northern part of the county. Erosion associated with Cimarron River downcutting has eroded the ogallala and has removed it from the southeastern part of Clark county. 
Ogallala sediments were, in large part, stream sediment derived from the Rocky Mountains approximately 300 miles to the west. Ogallala sediments spread eastward from the mountain front over the Great Plains in large alluvial-fan and riverine complexes following the Laramide orogeny which produced the present generation of Rocky Mountains about 40-80 ma. The Ogallala Formation is a major aquifer in the northern part of clark county and the adjacent region.

\section{Cretaceous Period \\ Kiowa Formation (Lower Cretaceous)}

Rocks of the Cretaceous Period in Clark County consist of olivegray to dark-gray fossiliferous shale and siltstone contained in the Kiowa Formation. Locally, the formation contains thin beds and laminations of dark-gray limestone and yellowish-brown, fine-grained, gypsiferous, sandstone and siltstone which generally occurs in the lower part of the formation. These sandstone beds and laminations are possible lateral equivalents of the Cheyenne Sandstone, also of Cretaceous age, present to the east in adjacent comanche county. The Cheyenne Sandstone lies stratigraphically below the Kiowa Formation. Cretaceous rocks lie unconformably over Permian red beds. Cretaceous rocks thin to the east and southeast within clark county and are truncated by pre-ogallala erosion in the southeastern part of the county. Some thinning of the Cretaceous sequence in clark County may also be attributed to depositional offlap of the Cretaceous sequence onto the eastern flank of the Hugaton Embayment.

Kiowa Formation sediment apparently was deposited mainly from the settling of suspended detrital sediment in the shallow sea that occupied the Rocky Mountain geosyncline during much of cretaceous time. Thin, flat-bedded sandy deposits within the Kiowa Formation, including sediment of the Cheyenne Sandstone present further east in Comanche county, probably were deposited by turbidity flow emanating down the continental slope from shore-line areas along the western margin of the seaway.

\section{Permian Period}

Red beds of Permian age form the area's most spectacular geologic outcrops. Formations crop out along several major tributaries of the Cimarron River, including Keiger Creek, Bluff Creek, Sandy Creek, and Day Creek. Upper Permian rocks, in descending order, are contained in the Big Basin Formation, the Day Creek Dolomite, and the Whitehorse Formation all three of which outcrop widely in the southern part of Clark County. Lower Permian rocks are contained in the Blaine Formation which outcrops only in the extreme southeastern part of the county along the banks of the Cimarron River. 
Permian rocks in Clark County are the products of sedimentary deposition in an arid environment within relatively shallow, restricted, marine bodies of water, i.e., embayments connected to a deep-water sea which lay to the south in the Anadarko basin of oklahoma. Permian sediments apparently were carried from the west (Swineford, 1955, p. 166) by wind into the Clark County region and deposited within a trade-wind desert that occupied the region throughout Permian time. A paleo-equator lay to the north in the vicinity of wyoming (Mack and others, p. 7, 1979). Environments of deposition associated with Permian sediments include coastal sabkha, tidal-flat, littoral marine, and evaporite basin. No evidence of fluvial environments associated with Permian rocks was identified in or near Clark County.

\section{Big Basin Formation (Upper Permian)}

The Big Basin Formation, formerly named the "Tologa Formation" (O'Conner, 1963), consists of mottled, dark-reddish-brown argillaceous siltstone locally containing dolomite and montmorillonite. Locally, the formation contains thin beds of silty shale, silty very fine grained sandstone, and gypsum/anhydrite. Where dolomitic, the siltstone is well indurated and has a hackly fracture. The detrital fraction of the formation contains a significant portion of montmorillonite, a swelling clay derived from the weathering of volcanic rocks. When wetted, the clay swells and forms a crusty surfaces at the outcrop. The presence of montmorillinite in the Big Basin Formation constitutes a potential geologic hazard by virtue of the adverse effect that swelling clay may have on buildings and foundations underlain by the formation. The presence of montmorillonite in the unit probably marks a change in sediment source areas for Permian rocks in the region from non-volcanic to volcanic since older Permian rocks do not apparently contain montmorillinite.

Deposition of sediment in this formation apparently occurred by suspended sediment settling and chemical precipitation from sea water in a restricted marine embayment under arid to semi-arid environments. The Formation ranges from 0 to about 80 feet in thickness and is truncated by pre-Kiowa erosion that proceeded in a south-southeasterly direction in the county.

\section{Day Creek Dolomite (Upper Permian)}

The Day Creek Dolomite consists of light-gray, pink, and white, dense, very fine grained, laminated, crystalline dolomite; locally, the unit contains chert nodules and disseminated chert grains. Formation of the unit probably occurred by chemical alteration of limestone precipitated from sea water by a process known as reflux dolomitization. The process apparently occurred in a broad tidal-flat under arid to semi-arid environments (Lucia, 1972, p. 163). The formation is present in the central and northern part of Clark County and forms an erosion-resistant bench trending east-west in the central part of the county. It is conformable with underlying and overlying formations. The unit ranges from 0 feet in the southern part of the county where it has been truncated by pre-kiowa and or pre-ogallala erosion to about 2 feet thick in the central and northern parts of the county. 


\section{Whitehorse Formation (Upper Permian)}

The Whitehorse Formation consists mainly of reddish-orange nonstratified, argillaceous siltstone. Locally it includes some minor thin beds of very fine grained, crossbedded, silty sandstone and thin beds of dolomite. It also contains gypsum and anhydrite in the subsurface. The unit is locally bleached white along bedding planes, is moderately friable, and characteristically contains round marblesized sandy calcareous concretions. Siltstone and sandstone are well sorted, well rounded, and consist mostly of iron oxide-stained quartz. Some dark accessory minerals are also present. Sediment deposition apparently occurred from the subaqueous settling of suspended sediment in relatively shallow marine waters of a restricted embayment. The character of the detrital fraction of sediment in whitehorse rocks suggests that detrital sediment was transported into the embayment primarily as loess (silt and very fine grained sand) winnowed into aerial suspension by seaward blowing winds associated with the migration of dune fields inland to the embayment. Apparently, lowenergy subaqueous currents acted locally to form a few low angle crossbedded units. Beds are characteristically wavy because of deformation caused by dissolution of gypsum and anhydrite beds associated with the sequence. In Clark County the whitehorse ranges from 150 to 250 feet thick.

\section{Blaine Formation (Lower Permian)}

The Blaine Formation consists of light-gray to white gypsum locally interbedded with thin beds of reddish-orange siltstone. Deposition apparently occurred by evaporation and subsequent chemical precipitation of gypsum from permian sea water in a marine embayment which had a restricted connection to the main Anadarko seaway, i.e., an evaporite basin. Thin siltstone beds probably represent eolian loess and were formed in a manner similar to that of siltstone in the overlying Whitehorse Formation. Within Clark County, the Blaine crops out only in the extreme southeast corner of the county in banks of the Cimarron River along the Comanche-Clark County line. The base of the formation is not exposed; however, exposed thickness of the formation is about $50 \mathrm{ft}$. 


\section{REFERENCES CITED}

Fairer, George M. and Green, Morris W., 1992, Preliminary geologic map of the Bloom SW quadrangle and parts of the Bloom, Minneola, and Fowler SE quadrangles, Clark County, Kansas: U.S. Geological Survey Open-file Report 92-698, 10 p., 1 pl., scale 1:24,000.

Fairer, George M. and Green, Morris W., 1994a, Preliminary geologic map of the Ashland NW quadrangle and parts of the Englewood, Profitt Lake, and Mount Helen quadrangles, Clark County, Kansas: U.S. Geological Survey Open-file Report 94-655, 7 p., 1 pl., scale $1: 24,000$.

Fairer, George M. and Green, Morris W., 1994b, Preliminary geologic map of the Ashland quadrangle and part of the Ashland SE quadrangle, Clark County, Kansas: U.S. Geological Survey Openfile Report 94-657, 6 p., 1 pl., scale 1:24,000.

Green, Morris W. and Fairer, George M., 1992, Preliminary geologic map of the Bloom SE quadrangle and part of the Simmons Creek quadrangle, Clark County, Kansas: U.S. Geological Survey Openfile Report 92-697, 7 p., 1 pl., scale 1:24,000.

Green, Morris W. and Fairer, George M., 1994a, Preliminary geologic map of the Mount Jesus quadrangle and parts of the Mount Jesus NW, Lexington, and Turkey Creek quadrangles, Clark County,

Kansas: U.S. Geological Survey Open-file Report 94-656, 8 p., 1 pl., scale $1 ; 24,000$.

Green, Morris W. and Fairer, George M., 1994b, Preliminary geologic map of the sitka quadrangle and parts of the Sitka sw, Sugarloaf, and Trout Creek quadrangles, Clark County, Kansas: U.S. Geological Survey Open-file Report 94-658, 7 p., 1 pl., scale $1: 24,000$.

Lucia, F.J., 1972, Recognition of evaporite-carbonate shoreline sedimentation; in Rigley, J.K. and Hamblin, W.K., eds., Recognition of ancient sedimentary environments: Society of Economic Paleontologists and Mineralogists, Special Publication no. $16, \mathrm{p}$ 160-191

Mack, G.H., Suttner, L.J., and Jennings, J.R., 1979, PermoPennsylvanian climatic trends in the ancestral Rocky Mountains: in Baars, D.L., ed., 1979, Permianland, A Field Symposium Guidebook of the Four Corners Geological Society, Nineth Field Conference, September 27-30, 1979, 186 p.

Maher, J.C. and Collins, J.B., 1949, Pre-Pennsylvanian geology of southwestern Kansas, southeastern Colorado, and oklahoma Panhandle: U.S. Geol. Survey Oil and Gas Inv. Prelim, Map 101, 4 sheets 
Merriam, D.F., 1963, The Geologic history of Kansas; Kansas Geol. Survey Bull. 162, $317 \mathrm{p}$.

Mudge, Melville R., 1967, Midcontinent region, in Mckee, E.D. Oriel, S.S. and others; Paleotectonic investigations of the Permian System in the United States: U.S. Geological Survey Professional Paper 515, 271 p., $6 \mathrm{pl}$.

O'Connor, H.G., 1963, Changes in Kansas stratigraphic nomenclature; American Association of Petroleum Geologists Bull., v.47, 18731877

Shimer, J.A., 1972, Field guide to landforms in the United States; The Macmillan Company, New York, New York, 272 p.

Stewart, G.F., 1975, Paleotectonic investigations of the Pennsylvanian System in the United States; Part I: Introduction and regional analysis of the Pennsylvanian System - Kansas: U.S. Geological Survey Professional Paper 853-H, p. 127-156.

Swineford, Ada, 1955, Petrography of Upper Permian rocks in southcentral Kansas: Kansas Geol. Survey Bull. 111, 179 p.

Zeller, D.E., ed., 1968, The stratigraphic succession in Kansas; Kansas Geol. Survey Bull. 189, 81 p. 